\title{
ABOUT THE TYPES OF HOMOGENOUS LINEAR DIFFERENTIAL EQUATIONS OF SECOND ORDER AND THEIR SOLUTIONS
}

\author{
Lazo Dimov
}

\begin{abstract}
In the paper, types of linear differential equations of second order are defined in the sense of the known classification of the types of linear partial differential equations of second order. Then the shapes of their solutions are examined and some classes differential equations are solved.
\end{abstract}

\section{Part 1}

For the linear partial differential equations of second order

$$
A \frac{\partial^{2} z}{\partial x^{2}}+2 B \frac{\partial^{2} z}{\partial x \partial y}+C \frac{\partial^{2} z}{\partial y^{2}}+D \frac{\partial z}{\partial x}+E \frac{\partial z}{\partial y}+F z+G=0,
$$

where $A, B, C, D, E, F$ and $G$ are real functions from the two variables $x$ and $y$, depending on the value of the determinant

$$
\Delta=\left|\begin{array}{ll}
A & B \\
B & C
\end{array}\right|,
$$

we have the following classification:

1. If $\Delta<0$, it is a PDE of hyperbolic type.

2. If $\Delta=0$, it is a PDE of parabolic type.

3. If $\Delta>0$, it is a PDE of elliptic type.

Here, we will make a similar classification for the homogenous linear differential equations of second order. It is well known that the equation

$$
y^{\prime \prime}+A y=0
$$

2010 Mathematics Subject Classification. 34A05, 34A30.

Key words and phrases. classification, elliptic type, parabolic type, hyperbolic type, differential equation with constant coefficients. 
where $A=$ const (equation 2.9 on page 365 in [2]), has a solution which can be written with the formula

$$
\begin{aligned}
& y(x)=c_{1} \sin \sqrt{A} x+c_{2} \cos \sqrt{A} x, \text { for } A>0 \\
& y(x)=c_{1} x+c_{2}, \text { for } A=0 \\
& y(x)=c_{1} \operatorname{sh} \sqrt{-A} x+c_{2} \operatorname{ch} \sqrt{-A} x, \text { for } A<0 .
\end{aligned}
$$

By analogy with the classification of the linear PDE of second order that we made, we can make the following classification for the equation (1) and its solution (2):

1. If $A<0$, it is an equation of hyperbolic type.

2. If $A=0$, it is an equation of parabolic type.

3. If $A>0$, it is an equation of elliptic type.

If $A=a(x)$ is a given function, then we can make the following classification of the equation (1), which now has the form

$$
y^{\prime \prime}+a(x) y=0
$$

and its solution as well, i.e.:

1. An equation of hyperbolic type, if $a(x)<0$.

2. An equation of parabolic type, if $a(x)=0$.

3. An equation of elliptic type, if $a(x)>0$.

For the solution of the equation (3) for every type, we examine the following formulas:

$$
\begin{aligned}
& y(x)=c_{1} \sin _{a(x)} x+c_{2} \cos _{a(x)} x, \text { for } a(x)>0 \\
& y(x)=c_{1} x+c_{2}, \text { for } a(x)=0 \\
& y(x)=c_{1} \operatorname{sh}_{a(x)} x+c_{2} \operatorname{ch}_{a(x)} x, \text { for } a(x)<0 .
\end{aligned}
$$

Here, the functions $\sin _{a(x)} x, \cos _{a(x)} x, \operatorname{sh}_{a(x)} x, \operatorname{ch}_{a(x)} x$ are defined and determined in [3].

It is well known that if in the differential equation

$$
y^{\prime \prime}+f(x) y^{\prime}+g(x) y=0
$$

we introduce a new function given with

$$
y(x)=e^{-\frac{1}{2} \int f(x) d x} z(x)
$$

it will transform in the differential equation

$$
z^{\prime \prime}+a(x) z=0
$$

known as canonical equation, where

$$
a(x)=g(x)-\frac{1}{2} f^{\prime}(x)-\frac{1}{4} f^{2}(x) .
$$


Now, according to the previous classification we made, we get the following classification for the equation (5):

1. The equation (5) is of hyperbolic type, if $a(x)<0$.

2. The equation (5) is of parabolic type, if $a(x)=0$.

3. The equation (5) is of elliptic type, if $a(x)>0$.

Here, the solution of the equation (5), we get with the formulas:

$$
\begin{aligned}
& y(x)=e^{-\frac{1}{2} \int f(x) d x}\left[c_{1} \sin _{a(x)} x+c_{2} \cos _{a(x)} x\right], \text { for } a(x)>0 \\
& y(x)=e^{-\frac{1}{2} \int f(x) d x}\left[c_{1} x+c_{2}\right], \text { for } a(x)=0 \\
& y(x)=e^{-\frac{1}{2} \int f(x) d x}\left[c_{1} \operatorname{sh}_{a(x)} x+c_{2} \operatorname{ch}_{a(x)} x\right], \text { for } a(x)<0 .
\end{aligned}
$$

Example. The differential equation

$$
y^{\prime \prime}+2(x+k) y^{\prime}+\left(x^{2}+2 k x+2 k^{2}-k+1\right) y=0
$$

where

$$
f(x)=2(x+k), \quad g(x)=x^{2}+2 k x+2 k^{2}-k+1,
$$

and $k=$ const has a canonical equation

$$
z^{\prime \prime}+\left(k^{2}-k\right) z=0
$$

so, according to the formulas (2) has a solution

$$
\begin{aligned}
& z(x)=c_{1} \sin \sqrt{k^{2}-k x}+c_{2} \cos \sqrt{k^{2}-k x}, \text { if } k \in(-\infty, 0) \cup(1, \infty) \\
& z(x)=c_{1} x+c_{2} \text {, if } k=0 \text { and } k=1 \\
& z(x)=c_{1} e^{-\sqrt{k-k^{2}} x}+c_{2} e^{\sqrt{k-k^{2}} x}, \text { if } k \in(0,1) .
\end{aligned}
$$

Now, the given equation according to the formulas (9) has a solution:

$$
\begin{aligned}
& y(x)=e^{-\frac{x^{2}}{2}+k x}\left[c_{1} \sin \sqrt{k^{2}-k x}+c_{2} \cos \sqrt{k^{2}-k x}\right], \text { if } k \in(-\infty, 0) \cup(1, \infty) \\
& y(x)=e^{-\frac{x^{2}}{2}}\left[c_{1} x+c_{2}\right], \text { if } k=0 \\
& y(x)=e^{-\frac{x^{2}}{2}+x}\left[c_{1} x+c_{2}\right], \text { if } k=1 \\
& y(x)=e^{-\frac{x^{2}}{2}+k x}\left[c_{1} e^{-\sqrt{k-k^{2}} x}+c_{2} e^{\sqrt{k-k^{2}}}\right], \text { if } k \in(0,1) .
\end{aligned}
$$




\section{PART 2}

If we introduce a new independent variable in the equation (5) with the relation $x=x(t)$, in order to get the equation (5) shaped as (1), we get that the functions that appear in the equation, satisfy the condition

$$
g^{\prime}(x)+2 f(x) g(x)=0
$$

and we get the new variable from the relation

$$
x^{\prime}(t)^{2}=\frac{A}{g(x)} .
$$

From (11) we have the following:

1. for $g(x)>0$ we have $A>0$, so the equation becomes an equation from elliptic type, where the connection between the new and the old variable is $\sqrt{A} t=\int \sqrt{g(x)} d x$.

2. for $g(x)<0$ we have $A<0$, so the equation becomes an equation from hyperbolic type, where the connection between the new and the old variable is $\sqrt{-A} t=\int \sqrt{-g(x)} d x$.

3. if $g(x)=0$, we can say that the equation is from parabolic type. Actually, the equation is

$$
y^{\prime \prime}+f(x) y^{\prime}=0
$$

and its solution is given with the formula

$$
y(x)=c_{1} \int e^{-\int f(x) d x} d x+c_{2} .
$$

Now, for the general solution of this kind of equation according to the formula (2), we get the following formula:

$$
\begin{aligned}
& y(x)=c_{1} e^{-\int \sqrt{-g(x)} d x}+c_{2} e^{\int \sqrt{-g(x)} d x}, \text { for } g(x)>0 \\
& y(x)=c_{1} \int e^{-\int f(x) d x} d x+c_{2}, \text { for } g(x)=0 \\
& y(x)=c_{1} \sin \left(\int \sqrt{g(x)} d x\right)+c_{2} \cos \left(\int \sqrt{g(x)} d x\right), \text { for } g(x)<0 .
\end{aligned}
$$

Example. In the differential equation

$$
y^{\prime \prime}+\frac{1}{2 x} y^{\prime}+\frac{k}{x} y=0
$$

where the functions $f(x)=\frac{1}{2 x}$ and $g(x)=\frac{k}{x}$ satisfy the condition (10). So, according to the formulas (12), its solution is 


$$
\begin{aligned}
& y(x)=c_{1} e^{-2 \sqrt{-k x}}+c_{2} e^{2 \sqrt{-k x}}, \text { for } k x>0 \\
& y(x)=c_{1} \sqrt{x}+c_{2}, \text { for } k=0 \\
& y(x)=c_{1} \sin (2 \sqrt{k x})+c_{2} \cos (2 \sqrt{k x}), \text { for } k x<0 .
\end{aligned}
$$

\section{Part 3}

Here we will explore the differential equation of second order with positive constant coefficients

$$
y^{\prime \prime}(t)+2 a y^{\prime}(t)+b^{2} y(t)=0
$$

(in [5] it is explored with dimensional constants). The characteristic equation of the equation (13) is

$$
r^{2}+2 a r+b^{2}=0
$$

Its solutions are

$$
r_{1 / 2}=-a \pm \sqrt{a^{2}-b^{2}} \text {. }
$$

It is useful to write them in the following shape

$$
r_{1 / 2}=\left(-\frac{a}{b} \pm \sqrt{\left(\frac{a}{b}\right)^{2}-1}\right) b=(-k \pm \sqrt{l}) b, \quad k=\frac{a}{b}, l=k^{2}-1 .
$$

Now, depending on the value of $l$, we make the following classification of the equation (13):

1. for $l<0$ i.e. $k<1$, the equation is an equation from elliptic type,

2. for $l=0$ i.e. $k=1$, the equation is an equation from parabolic type,

3. for $l>0$ i.e. $k>1$, the equation is an equation from hyperbolic type. Its solution is given with the formulas:

$$
\begin{aligned}
& y(x)=e^{-b t k}\left(c_{1} \cos \sqrt{-l} b t+c_{2} \sin \sqrt{-l} b t\right), \text { for } l<0, \text { i.e. } k<1 \\
& y(x)=e^{-b t}\left(c_{1}+c_{2} t\right), \text { for } l=0 \text {, i.e. } k=1 \\
& y(x)=c_{1} e^{b t m}+c_{2} e^{b t n}, \text { for } l>0 \text {, i.e. } k>1 \text {, where } m=-k-\sqrt{l}, n=-k+\sqrt{l} .
\end{aligned}
$$

Now, if in the differential equation (5) we introduce new independent variable with the relation $x=x(t)$, in order to get the equation (5) shaped as the differential equation (13), we get that the following conditions have to be satisfied

$$
\begin{gathered}
f(x) x^{\prime}(t)-\frac{x^{\prime \prime}(t)}{x^{\prime}(t)}=2 a \\
g(x) x^{\prime}(t)^{2}=b^{2} .
\end{gathered}
$$

Eliminating $t$ from (15) and (16) we get 


$$
\frac{2 g(x) f(x)+g^{\prime}(x)}{4 g(x) \sqrt{g(x)}}=\frac{a}{b}=k .
$$

Now, if we find the derivative of (17) we get the functional connection:

$$
2 f(x) g(x) g^{\prime}(x)-4 g^{2}(x) f^{\prime}(x)-2 g(x) g^{\prime \prime}(x)+3 g^{\prime}(x)^{2}=0
$$

which in fact is the condition that has to satisfy the functions $f(x)$ and $g(x)$ in order the equation (5) to be able to transform into (13).

From (16) we come to the connection between the old and the new independent variable:

$$
b t=\int \sqrt{g(x)} d x .
$$

So, we have proven the following theorem:

Theorem. The differential equation (5) can be transformed into a differential equation of type (13) if the functions $f(x)$ and $g(x)$ satisfy the condition (18) and the new independent variable is given with the relation (19). Here, we get the general solution according to the formulas (14) in which we substitute $b t$ with (19) and the ratio $\frac{a}{b}=k$ is given with the formula (17).

For the general solution we have the formulas:

$$
\begin{aligned}
& y=e^{-k \int \sqrt{g(x)} d x}\left(c_{1} \cos l \int \sqrt{g(x)} d x+c_{2} \sin l \int \sqrt{g(x)} d x\right), \text { for } 0<k<1, l=\sqrt{1-k^{2}} . \\
& y=e^{-\int \sqrt{g(x)} d x}\left(c_{1}+c_{2} \int \sqrt{g(x)} d x\right), \text { for } k=1, \\
& y=c_{1} e^{m \int \sqrt{g(x)} d x}+c_{2} e^{n \int \sqrt{g(x)} d x}, \text { for } k>1, \text { where } m=-k-\sqrt{-l}, n=-k+\sqrt{-l} .
\end{aligned}
$$

Example 1. In the differential equation

$$
y^{\prime \prime}+\left(c \sqrt{x}-\frac{1}{2 x}\right) y^{\prime}+x y=0,
$$

the functions $f(x)=c \sqrt{x}-\frac{1}{2 x}$ and $g(x)=x$ satisfy the condition (18), for $k$ from (17) we get $k=\frac{c}{2}$. So, according to the formula for the substitute, we have

$$
\int \sqrt{g(x)} d x=\int \sqrt{x} d x=\frac{2}{3} x^{\frac{3}{2}}
$$

Depending on the value of $c$ we have the following forms for the solution of the differential equation

$$
y=e^{-\frac{c}{3} x^{\frac{3}{2}}}\left(c_{1} \cos \frac{1}{3} \sqrt{4-c^{2}} x^{\frac{3}{2}}+c_{2} \sin \frac{1}{3} \sqrt{4-c^{2}} x^{\frac{3}{2}}\right), \text { for } 0<c<2 .
$$




$$
\begin{gathered}
y=\left(c_{1}+c_{2} x^{\frac{3}{2}}\right) e^{-\frac{2}{3} x^{\frac{3}{2}}}, \text { for } c=2, \\
y=c_{1} e^{-\frac{c+\sqrt{c^{2}-4}}{3} x^{\frac{3}{2}}}+c_{2} e^{\frac{c+\sqrt{c^{2}-4}}{3} x^{\frac{3}{2}}} \text {, for } c>2 .
\end{gathered}
$$

Example 2. The Euler differential equation

$$
x^{2} y^{\prime \prime}+c x y^{\prime}+y=0
$$

written in shape (5) is

$$
y^{\prime \prime}+\frac{c}{x} y^{\prime}+\frac{1}{x^{2}} y=0
$$

The functions $f(x)=\frac{c}{x}$ and $g(x)=\frac{1}{x^{2}}$ satisfy the condition (18) and for $k$ from (17) we get $k=\frac{c-1}{2}$. So, according to the formula for the substitute, we have

$$
\int \sqrt{g(x)} d x=\int \frac{1}{x} d x=\ln x
$$

Depending on the value of $c$ we have the following forms for the solution of the differential equation

$$
\begin{aligned}
& y=e^{-\frac{c-1}{3}}\left(c_{1} \cos \frac{1}{2} \sqrt{3+2 c-c^{2}} \ln x+c_{2} \sin \frac{1}{2} \sqrt{3+2 c-c^{2}} \ln x\right), \text { for } 1<c<3, \\
& y=\left(c_{1}+c_{2} \ln x\right) \frac{1}{x}, \text { for } c=3, \\
& y=c_{1} e^{\frac{1-c-\sqrt{c^{2}-2 c-3}}{2}}+c_{2} e^{\frac{1-c+\sqrt{c^{2}-2 c-3}}{2}}, \text { for } c>3 .
\end{aligned}
$$

Note. In [2] on page 383, ex. 2.75 is proven that the differential equation (5) with similar substitution can be transformed into the differential equation with constant coefficients

$$
y^{\prime \prime}+a y^{\prime}+y=0
$$

which is a special case of the equation (13).

\section{References}

[1] Аинс, Объкновеньле дифференциальнье уравнения, ИЛ Москва, 1953

[2] Е. Камке, Справочник по объкновеньлм дифференциальныем уравнениям, ГИ Москва, 1951 
[3] Л. Стефановска, Нови квадратурни аспекти на теоријата на линеарните диференцијални равенки, $\mathrm{PhD}$ thesis, Skopje, 1994

[4] Д. Димитровски, Ј. Митевска, Линеарни тригонометрии од четврти и шести ред, ПМФ - Скопје, Посебни изданија

[5] B. Vujanović, D. Spasić, Metodi optimizacije, Univerzitet u Novom Sadu, Fakultet tehničkih nauka, 1997

[6] Л. Димов, За решавањето на една диференцијална равенка од втор ред, Математички билтен, Скопје, 1996

[7] Л. Димов, За обликот на решението на една линеарна диференцијална равенка од втор ред со функционални коефициенти, Осми македонски симпозиум по диференцијални равенки, Охрид, 30.09.2004-03.10.2004

[8] Л. Димов, За обликот на решението на една линеарна диференцијална равенка од трети ред со функичонални коефищиенти, Четврти конгрес на математичари на Македонија, Струга, 19-22.10.2008

[9] Л. Димов, За обликот на решението на една линеарна диференцијална равенка од втор ред со функционални коефициенти, (втор сепарат), Математички билтен 2011

Ss. Cyril and Methodius University Faculty of Mechanical Engineering, Skopje, R. Macedonia e-mail: lazo.dimov@mf.edu.mk 